\title{
STRATEGI NAFKAH DAN KESEJAHTERAAN KELUARGA PADA KELUARGA PETANI TADAH HUJAN
}

\author{
Adam Sugiharto $^{\left.1^{*}\right)}$, Hartoyo ${ }^{2}$, Istiqlaliyah Muflikhati² \\ ${ }^{1}$ Biro Umum, Badan Kependudukan dan Keluarga Berencana Nasional, Jakarta 13650, Indonesia \\ ${ }^{3}$ Departemen Ilmu Keluarga dan Konsumen, Fakultas Ekologi Manusia, Institut Pertanian Bogor, \\ Bogor 16680, Indonesia \\ *)E-mail: adam_satriadi@yahoo.co.id
}

\begin{abstract}
Abstrak
Keterbatasan yang dihadapi oleh keluarga petani akan menyebabkan keluarga menciptakan beberapa pilihan strategi nafkah. Penelitian ini bertujuan untuk menganalisis strategi nafkah dan pengaruhnya terhadap tingkat kesejahteraan keluarga petani tadah hujan di Kecamatan Playen Kabupaten Gunungkidul. Wilayah yang dijadikan lokasi penelitian adalah wilayah yang jauh dari ibukota kecamatan dan wilayah terdekat dari ibukota kecamatan. Penelitian ini melibatkan 100 keluarga yang diwawancara secara langsung menggunakan kuesioner. Data dianalisis menggunakan analisis deskriptif dan regresi logistik biner. Berdasarkan indikator tingkat kesejahteraan keluarga BKKBN, penelitian menemukan bahwa keluarga yang sejahtera sebanyak 57,0 persen dan sisanya tidak sejahtera. Secara keseluruhan, penelitian ini menemukan bahwa sebagian besar keluarga petani menjalankan strategi nafkah campuran. Hasil penelitian menunjukkan bahwa usia suami yang lebih muda, peningkatan pengeluaran per kapita, dan peningkatan modal fisik keluarga memengaruhi secara langsung kesejahteraan keluarga namun jenis strategi koping dan juga lokasi tidak memengaruhi kesejahteraan keluarga. Hasil tersebut mengindikasikan belum adanya pengaruh strategi koping terhadap kesejahteraan keluarga tadah hujan pada penelitian ini.
\end{abstract}

Kata kunci: kesejahteraan keluarga, strategi nafkah, keluarga petani, petani tadah hujan

\section{Livelihood Strategies and Family Welfare of Non-Irrigated Farm Family}

\begin{abstract}
Creating several livelihood strategies by families is an effect of limitation faced by families. This study aimed to analyze livelihood strategies and their effects on the welfare of non-irrigated farm families in Playen District of Gunung Kidul Regency. Region that is used as a location of study was an area which was far from the capital of district and nearby area of the capital of district. The study involved 100 families interviewed using a questionnaire. Data were analyzed using descriptive analysis and binary logistic regression. Based on indicator of family welfare level from BKKBN, the study found that the prosperous family is as much as 57.0 percent and the rest is not prosperous. Overall, the study found that majority of farmer family has mix livelihood strategies. The results showed that the age of husband which is younger, the increase of spending cost per capita, and the increase of physical capital of a family directly affect the welfare of the family. On the other hand, the kind of coping strategies of farmer family and also the location of the family does not affect the family welfare. These results indicate the absence of the influence of coping strategies towards family welfare of non-irrigated farm family in this study.
\end{abstract}

Keywords: family welfare, livelihood strategies, non-irrigated farm family

\section{PENDAHULUAN}

Pembangunan pertanian memiliki peranan yang strategis dalam penyerapan tenaga kerja di Indonesia. Hal ini dikarenakan kecukupan beras sebagai bahan makanan pokok penduduk Indonesia sebaiknya dipenuhi secara swasembada. Permintaan beras sebagai makanan utama sebagian besar penduduk Indonesia mengalami peningkatan dari tahun ke tahun. Peningkatan jumlah penduduk mendorong permintaan beras meningkat. Apabila tidak dilakukan peningkatan produktivitas dan perluasan areal panen, defisit beras di Indonesia akan meningkat sekitar 13,5 persen per tahun (Swastika, Hadi, \& Ilham, 2000). Sementara itu, pada saat yang sama Widodo (2006) mengungkapkan adanya gejala migrasi tenaga kerja sektor pertanian ke sektor nonpertanian melalui proses migrasi desa-kota dan migrasi internasional. Walaupun penelitian ini belum secara jelas membahas mengenai strategi nafkah, namun telah memberikan gambaran tentang usaha mempertahankan 
hidup melalui pencarian nafkah di luar sektor pertanian (Widodo, 2006). Ozturk (2009) melaporkan strategi berganti pekerjaan bagi para petani. Demikian pula mengenai fenomena migrasi, migrasi adalah diversifikasi nafkah yang umum selama musim kering sebagaimana temuan Olsson dan Elmqvist (2006). Siddique (2003) juga menyatakan bahwa migrasi berkontribusi pada strategi nafkah kaum miskin. Adanya kelangkaan sumber penghidupan yang memadai di perdesaan pada akhirnya menjadikan petani harus memilih untuk menerapkan strategi intensifikasi pada lahan pertanian yang dimilikinya atau melakukan strategi diversifikasi sumber nafkah. Kegiatan mendiversifikasi nafkah ini merupakan bentuk perjuangan rumah tangga petani menghadapi berbagai situasi (Turasih \& Wibowo, 2012). Sementara itu, Scoones (1998) juga melaporkan adanya strategi migrasi (keluar) berupa perpindahan dengan sukarela/sengaja atau tidak.

Mengacu pada Chambers dan Conway (1991) bahwa mata pencaharian (livelihood) merupakan kemampuan, aset, dan aktivitas yang diperlukan sebagai alat untuk hidup. Penghasilan yang rendah dari sektor pertanian mendorong petani untuk mencari alternatif tambahan penghasilan guna memenuhi kebutuhan keluarganya. Upaya yang dilakukan diantaranya menjalani pola nafkah ganda (Sumarti, 2007). Alasan utama melakukan strategi nafkah ganda berbeda pada masingmasing lapisan masyarakat. Pada rumah tangga lapisan atas, pola nafkah ganda merupakan strategi akumulasi modal dan lebih bersifat ekspansi usaha. Sementara itu, pada lapisan tengah pola nafkah ganda merupakan upaya konsolidasi untuk mengembangkan ekonomi rumah tangga. Sebaliknya pada lapisan paling bawah, pola nafkah ganda merupakan strategi bertahan hidup pada tingkat subsistensi dan sebagai upaya untuk keluar dari kemiskinan (Sajogyo, 1982). Menurut Sumarti (2007) pola nafkah ganda di pedesaan didefinisikan sebagai proses-proses yang mana rumah tangga membangun suatu kegiatan dan kapasitas dukungan sosial yang beragam untuk bertahan hidup dan untuk meningkatkan taraf hidupnya.

Namun, harapan sebenarnya dari keluarga petani adalah mampu keluar dari situasi kemiskinan menuju kepada kesejahteraan keluarga. Puspitawati, Simanjuntak, dan Hayati (2012) menyatakan bahwa tujuan keluarga adalah untuk mewujudkan kesejahteraan, baik kesejahteraan objektif maupun kesejahteraan subjektif. Tujuan terbentuknya keluarga adalah untuk mewujudkan keadaan sejahtera baik fisik, sosial, ekonomi, psikologis/ mental serta spiritual (Puspitasari, Puspitawari, \& Herawati, 2013). Kesejahteraan dapat diraih apabila semua sumber daya keluarga dapat dikelola dengan baik. Dalam konsepsi strategi nafkah, menurut Scoones (1998) keluarga memiliki 6 (enam) modal, salah satunya adalah modal politik, sedangkan DFID (2000) dan Ellis (1998) hanya menyebutkan 5 (lima) modal yaitu modal manusia, modal finansial, modal fisik, modal sosial, dan modal alam. Sebagai upaya untuk keluar dari kondisi kemiskinan, keluarga akan mengubah strategi nafkah dengan menggunakan sumber-sumber nafkah yang mereka miliki yaitu modal alam, modal manusia, modal finansial, modal fisik dan modal sosial (De Haan, 2000).

Penelitian tentang strategi nafkah dalam berbagai latar belakang ekologi yang berbeda dan parsial telah banyak dilakukan antara lain penelitian mengenai petani kentang oleh Turasih dan Wibowo (2012) dan petani tembakau oleh Widiyanto, Suwarto, dan Retno (2010), akan tetapi penelitian tentang pengaruh strategi nafkah pada keluarga petani tadah hujan terhadap tingkat kesejahteraan keluarga masih sangat minim dilakukan. Penelitian mengenai strategi nafkah petani tadah hujan menarik sebab data dari Kementerian Pertanian menyebutkan bahwa luas sawah beririgasi di Indonesia hanya 4.784.974 ha, sedangkan sawah tak beririgasi (tadah hujan, rawa lebak, pasang surut) seluas 7.748 .348 ha (Sihati, 2013). Oleh karena itu, penelitian ini bertujuan untuk: 1) Menganalisis karakteristik keluarga, modal sosial, strategi nafkah, dan kesejahteraan keluarga berdasarkan posisi geografis desa (desa dekat kota dan desa terpencil pada keluarga petani tadah hujan; 2) Menganalisis pengaruh karakteristik keluarga, modal sosial, dan strategi nafkah terhadap kesejahteraan keluarga petani tadah hujan.

\section{METODE}

Penelitian ini menggunakan desain cross sectional yang dilaksanakan di Desa Bandung dan Bleberan, Kecamatan Playen, Kabupaten Gunungkidul, Daerah Istimewa Yogyakarta. Pemilihan lokasi dilakukan secara purposive dengan pertimbangan 1) lokasi merupakan kawasan pertanian sistem tadah hujan dan 2) berdasarkan posisi geografis desa, yaitu desa dekat kota (Desa Bandung) dan desa terpencil (Desa Bleberan) (Gunarso, 2009). Pengambilan data dilakukan pada bulan September sampai dengan bulan Oktober 2014. 
Populasi pada penelitian ini adalah keluarga yang kepala keluarganya bekerja sebagai petani pemilik. Pemilihan keluarga contoh dilakukan secara acak sederhana (simple random sampling). Setiap desa dipilih masingmasing 50 keluarga dengan responden adalah suami dan atau istri, sehingga jumlah keseluruhan keluarga contoh adalah 100 keluarga. Data penelitian dikumpulkan melalui wawancara secara langsung dengan bantuan kuesioner. Data yang dikumpulkan terdiri atas karakteristik keluarga, modal strategi nafkah, dan tingkat kesejahteraan keluarga.

Data karakteristik keluarga meliputi jumlah anggota keluarga, usia suami dan istri, pendidikan suami dan istri, serta pengeluaran keluarga. Adapun kepemilikan dan akses terhadap modal strategi nafkah meliputi modal sosial, modal finansial, modal alam, dan modal fisik. Modal strategi nafkah yang hanya bisa diakses namun tidak dapat dimiliki terdiri atas modal sosial dan modal alam. Modal finansial diukur dari besarnya nilai uang tunai di rumah, tabungan di bank, piutang, dan simpanan emas yang keseluruhannya dihitung sebagai rupiah. Sementara itu, modal fisik diukur dari besarnya nilai hewan ternak, kendaraan, peralatan, rumah, dan tanah yang keseluruhannya dihitung dalam rupiah. Instrumen yang digunakan untuk meneliti modal manusia, modal finansial, dan modal fisik pada penelitian ini mengacu pada instrumen Livelihood Assesment Tool-kit/LAT (ILO \& FAO, 2009).

Modal sosial diukur berdasarkan indeks kepercayaan dalam keluarga (trust), norma (norms), dan jaringan (networking). Instrumen modal sosial yang digunakan dalam penelitian ini telah dimodifikasi dari instrumen modal sosial Narayan dan Casidy (1999), Alfiasari (2008), Minamoto (2010), dan Widodo (2011). Kepercayaan dalam keluarga terdiri atas 5 pertanyaan yang disusun secara Likert dengan pilihan jawaban 1 =sangat tidak percaya, 2=tidak percaya, 3=agak percaya, 4=percaya, dan $5=$ sangat percaya. Norma di dalam keluarga (norms) terdiri atas 5 pertanyaan yang disusun secara Likert mulai dari 1=tidak pernah (0 x), 2=kadang-kadang (1 x per bulan), $3=$ jarang $(2 \times$ per bulan), $4=$ sering $(3 \times$ per minggu), dan $5=$ selalu (setiap hari); dan jejaring (networking) terdiri atas 10 pertanyaan dengan urutan 1 =tidak ada (0 lembaga/orang), 2=ada dan sedikit (1-2 lembaga/orang), 3=ada dan cukup (3-5 lembaga/orang), 4=ada dan banyak (6-10 lembaga/orang), 5=ada dan sangat banyak (> 10 lembaga/orang, $6=$ tidak pernah $(0$ $\mathrm{x}), 7$ =kadang-kadang (1 $\mathrm{x}$ per 6 bulan), $8=$ jarang ( $1 \times$ per bulan), $9=$ sering $(\geq 3 \times$ per bulan), 10=selalu (setiap hari). Instrumen ini memiliki nilai Cronbach's alpha sebesar 0,769. Masing-masing skor modal sosial trust, norms, dan networking yang diperoleh dijumlahkan dan dihitung indeksnya. Selanjutnya, nilai indeks dibagi menjadi tiga kategori, yaitu rendah (indeks 0,0-33,3), sedang (indeks 33,4-66,7), dan tinggi (indek 66,8-100,0).

Modal alam mengukur akses keluarga petani terhadap modal alam yang ada di lingkungan sekitar keluarga. Instrumen modal alam dikembangkan dari Livelihood Assessment Tool-kit /LAT (ILO \& FAO, 2009) yang terdiri atas 4 pertanyaan. Tiap butir pertanyaan memiliki lima jawaban dengan skala Likert yaitu $1=$ tidak pernah $(0 x), 2=$ kadang-kadang $(2 \times$ per bulan), 3=sering (3-4 $x$ per bulan), dan $4=$ selalu (setiap hari). Jawaban diperoleh jumlahkan dan dihitung indeksnya, kemudian dikelompokkan menjadi tiga kategori yaitu rendah (indeks 0,033,3 ), sedang (indeks 33,4-66,7), dan tinggi (indek 66,8-100,0).

Strategi nafkah merupakan kemampuan, aset, dan aktivitas yang diperlukan sebagai alat untuk hidup (Chambers \& Conway, 1992). Besar kecilnya kepemilikan tiap aset modal menjadikan pilihan strategi nafkah tiap keluarga juga berbeda-beda. Strategi nafkah dikelompokkan menjadi strategi nafkah tunggal (pertanian dan peternakan) dan campuran (kombinasi antara pertanian, migrasi, dan wirausaha lain di luar pertanian). Instrumen strategi nafkah digunakan untuk mengukur cara keluarga petani menerapkan kombinasi pilihan strategi nafkah untuk memenuhi kebutuhan keluarga. Instrumen ini dikembangkan dengan pendekatan teori strategi nafkah Ellis (1998), Scoones (1998), DFID (2000), Siddique (2003), dan Sumarti (2007).

Kesejahteraan keluarga diukur dengan menggunakan indikator BKKBN dan dikategorikan menjadi keluarga prasejahtera (PraKS), keluarga sejahtera I (KS I), keluarga sejahtera II (KS II), keluarga sejahtera III (KS III), dan keluarga sejahtera III Plus (KS III Plus). PraKS dan KS dikelompokkan menjadi keluarga tidak sejahtera, sedangkan KS II, KS III, dan KS III plus termasuk ke dalam kelompok keluarga sejahtera.

Keluarga prasejahtera adalah keluarga yang belum dapat memenuhi salah satu indikator tahapan Keluarga Sejahtera I. Keluarga Sejahtera I adalah keluarga yang baru dapat memenuhi indikator-indikator berikut: (1) Pada umumnya anggota keluarga makan dua kali sehari atau lebih; (2) Anggota keluarga memiliki 
pakaian yang berbeda untuk di rumah, bekerja/sekolah dan bepergian; (3) Rumah yang ditempati keluarga mempunyai atap, lantai, dinding yang baik; (4) Bila ada anggota keluarga sakit dibawa ke sarana kesehatan; (5) Bila pasangan usia subur ingin ber KB pergi ke sarana pelayanankontrasepsi; (6) Semua anak umur 7-15 tahun dalam keluarga bersekolah.

Keluarga Sejahtera II merupakan keluarga yang sudah dapat memenuhi indikator Tahapan Keluarga Sejahtera I (indikator $1 \mathrm{~s} / \mathrm{d}$ 6) dan indikator berikut; (7) Pada umumnya anggota keluarga melaksanakan ibadah sesuai dengan agama dan kepercayaan masing-masing; (8) Paling kurang sekali seminggu seluruh anggota keluarga makandaging/ikan/telur; (9) Seluruh anggota keluarga memperoleh paling kurang satu pasang pakaianbaru dalam setahun; (10) Luas lantai rumah paling kurang $8 \mathrm{~m} 2$ untuk setiap penghuni rumah; (11) Tiga bulan terakhir keluarga dalam keadaan sehat, sehingga dapat melaksanakan tugas/fungsi masing-masing; (12) Ada seorang atau lebih anggota keluarga yang bekerja untuk memperoleh penghasilan; (13) Seluruh anggota keluarga umur 10-60 tahun bisa baca tulisan latin; (14) Pasangan usia subur dengan anak dua atau lebih menggunakan alat/obat kontrasepsi.

Keluarga Sejahtera III adalah keluarga yang sudah memenuhi indikator Tahapan Keluarga Sejahtera I dan Keluarga Sejahtera II (Indikator $1 \mathrm{~s} / \mathrm{d}$ 14) dan indikator: (15) Keluarga berupaya meningkatkan pengetahuan agama; (16) Sebagian penghasilan keluarga ditabung dalam bentuk uang atau barang; (17) Kebiasaan keluarga makan bersama paling kurang seminggu sekali dimanfaatkan untuk berkomunikasi; (18) Keluarga ikut dalam kegiatan masyarakat di lingkungan tempat tinggal; (19) Keluarga memperoleh informasi dari surat kabar/majalah/radio/tv. Keluarga Sejahtera III Plus merupakan keluarga yang memenuhi indikator Tahapan keluarga Sejahtera I, Keluarga Sejahtera II, dan Keluarga Sejahtera III (Indikator 1s/d 19) dan indicator: (20) Keluarga secara teratur dengan suka rela memberikan sumbangan materiil untuk kegiatan sosial; (21) Ada anggota keluarga yang aktif sebagai pengurus perkumpulan sosial/yayasan/institusi masyarakat.

Pendekatan pengeluaran digunakan untuk menggambarkan kondisi ekonomi keluarga dalam karena dinilai lebih mendekati kondisi riil keluarga miskin. Pendekatan pengeluaran juga dinilai lebih memudahkan dalam mengetahui jumlah penghasilan keluarga petani yang sesungguhnya. Penghasilan petani dihitung langsung dengan pendapatan per kapita keluarga petani terkendala karena keluarga petani tidak mencatat setiap pemasukan keuangan keluarga dan banyak aktivitas petani yang dianggap sebagai pendapatan, namun tidak menghasilkan rupiah. Penghitungan pendapatan keluarga dengan cara ini pernah dilakukan oleh Alfiasari (2008). Pendapatan keluarga adalah rata-rata besarnya penghasilan yang diperoleh anggota keluarga. Namun, penilaian tingkat kesejahteraan keluarga petani melalui pendekatan pendapatan sangat sulit dilakukan, oleh karena itu sebagai pendekatan (proksı) atas besarnya pendapatan keluarga pada penelitian ini digunakan pendekatan pengeluaran per kapita keluarga.

Analisis deskriptif digunakan untuk menggambarkan karakteristik keluarga, modal, strategi nafkah, dan kesejahteraan keluarga. Analisis data yang digunakan dalam penelitian ini adalah analisis deskriptif dan analisis regresi logistik biner. Uji regresi logistik biner untuk menganalisis pengaruh karakteristik keluarga, modal strategi nafkah, strategi nafkah yang diterapkan dan lokasi penelitian terhadap tingkat kesejahteraan keluarga.

\section{HASIL}

\section{Karakteristik Keluarga}

Tabel 1 menunjukkan bahwa rata-rata jumlah anggota keluarga petani di desa dekat kota lebih sedikit (3,82 jiwa) dibandingkan dengan rata-rata jumlah anggota keluarga petani di desa terpencil (4,40 jiwa). Rata-rata usia suami dan istri pada keluarga petani di desa dekat kota lebih tinggi daripada rata-rata usia suami pada keluarga di desa terpencil.

Tabel 1 Nilai rata-rata dan standar deviasi karakteristik keluarga berdasarkan lokasi tempat tinggal

\begin{tabular}{lccc}
\hline $\begin{array}{l}\text { Karakteristik } \\
\text { keluarga }\end{array}$ & $\begin{array}{c}\text { Desa dekat } \\
\text { kota }\end{array}$ & $\begin{array}{c}\text { Desa } \\
\text { terpencil }\end{array}$ & Total \\
\hline Jumlah anggota & $3,82 \pm$ & $4,40 \pm$ & $4,11 \pm$ \\
keluarga (jiwa) & 1,45 & 1,22 & 1,37 \\
Usia Suami & $60,00 \pm$ & $49,72 \pm$ & $54,86 \pm$ \\
(tahun) & 9,26 & 11,96 & 11,83 \\
Usia Istri (tahun) & $53,12 \pm$ & $43,98 \pm$ & $48,55 \pm$ \\
& 10,25 & 11,02 & 11,54 \\
Lama pendidikan & $9,76 \pm$ & $8,46 \pm$ & $9,11 \pm$ \\
suami (tahun) & 3,12 & 2,69 & 2,98 \\
Lama pendidikan & $8,48 \pm$ & $7,80 \pm$ & $8,14 \pm$ \\
istri (tahun) & 3,96 & 3,49 & 3,73 \\
Pengeluaran per & $435.54 \pm$ & 366,34 & $400,94 \pm$ \\
kapita (Rp000/ & 186,99 & \pm & 163,17 \\
bulan) & & 127,99 & \\
\hline
\end{tabular}


Rata-rata lama pendidikan yang ditempuh suami pada keluarga di desa dekat kota dan desa terpencil masing-masing adalah 9,76 tahun dan 8,46 tahun. Adapun rata-rata lama pendidikan yang ditempuh istri pada keluarga di dekat kota adalah 8,48 tahun, sedangkan di desa terpencil adalah 7,80 tahun. Sementara itu, untuk pengeluaran keluarga di desa dekat kota adalah Rp435.540 per kapita per bulan, sedangkan pengeluaran keluarga yang berada di desa terpencil yaitu Rp366.340 per kapita per bulan. Adapun rata-rata pengeluaran per kapita per bulan keluarga petani di kedua desa adalah Rp400.940 dengan standar deviasi Rp. 163,17

\section{Kepemilikan dan Akses terhadap Modal Strategi Nafkah}

Modal sosial. Modal sosial mengukur besarnya tingkat pemanfaatan oleh keluarga sebagai pilihan strategi nafkah. Modal keluarga dapat menggerakkan intuisi, minat, ketertarikan, dan kerelaan seseorang untuk saling membantu dalam kehidupan berkeluarga dan bermasyarakat baik ketika diminta maupun tidak diminta. Hasil penelitian menunjukkan bahwa pada desa dekat kota (Desa Bandung) hanya sebanyak 90,0 persen keluarga yang memanfaatkan modal sosial dalam kategori tinggi. Hasil yang sama pada desa terpencil (Desa Bleberan) memanfaatkan modal sosial pada kategori tinggi, yaitu sebanyak 96,0 persen. Rata-rata indeks pemanfaatan modal sosial untuk desa yang dekat kota (Desa Bandung) adalah 75,88 dengan standar deviasi 6,96 , sedangkan rata-rata pemanfaatan modal sosial untuk desa terpencil (Desa Bleberan) adalah 79,41 dengan standar deviasi 10,62. Rata-rata total pemanfaatan modal sosial untuk kedua desa adalah 77,65 dengan standar deviasi 9,11.

Tabel 2 Rata-rata dan standar deviasi kepemilikan jenis modal berdasarkan lokasi tempat tinggal

\begin{tabular}{lccc}
$\begin{array}{l}\text { Jenis } \\
\text { modal }\end{array}$ & $\begin{array}{c}\text { Desa dekat } \\
\text { kota }\end{array}$ & $\begin{array}{c}\text { Desa } \\
\text { terpencil }\end{array}$ & Total \\
\hline $\begin{array}{l}\text { Modal } \\
\text { sosial } \\
\text { (indeks) }\end{array}$ & $75,88 \pm 6,96$ & $79,41 \pm 10,62$ & $77,67 \pm 9,11$ \\
Modal & $6.063 .100 \pm$ & $2.779 .300 \pm$ & $4.421 .200 \pm$ \\
finansial & 10.460 .200 & 8.888 .100 & 9.798 .300 \\
(Rp) & & & \\
Modal & $38,15 \pm 15,89$ & $68,15 \pm 16,38$ & $53,15 \pm 22,00$ \\
alam & & & \\
(indeks) & & & \\
Modal & 181.440 .000 & 134.210 .000 & 157.820 .000 \\
fisik & \pm & \pm & \pm \\
(Rp) & 95.596 .500 & 136.009 .000 & 119.340 .000
\end{tabular}

Modal finansial. Modal sosial dalam penelitian ini mengacu pada jenis yang disebutkan oleh ILO dan FAO (2009) antara lain berupa simpanan uang tunai di rumah, tabungan di bank, piutang, dan simpanan dalam bentuk logam mulia (emas). Hasil penelitian pada Tabel 2 menunjukkan rata-rata total nilai kepemilikan modal finansial keluarga petani di desa dekat kota lebih tinggi yaitu Rp.6.063.100 dibandingkan dengan keluarga di desa terpencil yaitu Rp. 2.779.300.

Modal alam. Modal alam didefinisikan sebagai adanya akses keluarga terhadap hutan, sungai, pantai, laut, danau, kehidupan liar, dan biodiversitas yang menunjang strategi nafkah keluarga (ILO \& FAO, 2009). Desa dekat kota dan desa terpencil di Kecamatan Playen memiliki fasilitas pengairan dan potensi wisata yang tidak setara. Desa Bleberan (desa terpencil) memiliki aliran Sungai Oyo dan lokasi ekowisata berupa air terjun Sri Gethuk, Goa Ngrancang Kencono, dan hutan Perhutani, sedangkan Desa Bandung (desa dekat kota) tidak memiliki keempat hal tersebut. Meskipun terdapat fasilitas susia bor di Desa Bandung dan Sungai Oyo di Desa Bleberan, keluarga petani di kedua desa penelitian tidak seluruhnya mengakses modal alam yang tersedia ini.

Pada keluarga yang tinggal di desa dekat kota, sebanyak 58,0 persen keluarga petani memanfaatkan modal alam pada kategori sedang (indeks 33,4-66,7) dan 42,0 persen keluarga memanfaatkan modal alam kategori rendah (indeks 0,0-33,3). Sementara itu, lebih dari separuh keluarga petani $(68 \%)$ pada desa terpencil cenderung melakukan pemanfaatan modal alam kategori tinggi (indeks 66,7-100,0), sedang $(28,0 \%)$, dan rendah $(4,0 \%)$. Hasil ini menunjukkan bahwa keluarga petani di desa terpencil memanfaatkan modal alam dengan lebih baik dibandingkan dengan keluarga petani di desa dekat kota. Rata-rata pemanfaatan modal alam untuk desa dekat kota dan desa terpencil adalah 38,15 dengan standar deviasi 15,89 , sedangkan untuk desa terpencil 68,15 dengan standar deviasi 16,38. Rata-rata besarnya indeks pemanfaatan modal sosial untuk kedua desa adalah sebesar 53,15 dengan standar deviasi 22,0.

Modal fisik. Modal fisik merupakan modal keluarga berupa barang bergerak dan tidak bergerak yang dimiliki sendiri dan dapat menunjang pilihan strategi nafkah keluarga. Modal fisik dihitung berdasarkan kepemilikan ternak, peralatan elektronik, mebeler, kendaraan, dan mesin produktif lainnya, rumah, 
sawah, ladang dan pekarangan. Modal fisik dinilai dalam satuan rupiah. Keluarga petani di desa dekat kota memiliki nilai mebeler, rumah, dan pekarangan yang lebih tinggi dibandingkan dengan keluarga petani di desa terpencil. Ratarata total dan standar deviasi nilai modal fisik keluarga petani di desa dekat kota (Desa Bandung) dan desa terpencil (Desa Bleberan) disajikan pada Tabel 2.

\section{Strategi Nafkah}

Strategi nafkah merupakan strategi pencarian sumber penghidupan yang bisa ditekuni untuk membiayai segala kebutuhan seluruh anggota keluarga dalam jangka panjang baik di saat miskin maupun disaat sejahtera (dinyatakan sebagai strategi intensifikasi lahan pertanian jika hanya menekuni pertanian dan peternakan, dan diversifikasi strategi nafkah jika menekuni bidang pertanian dan wiraswasta nontani, petani serta migrasi jika melakukan migrasi).

Keluarga petani di Kecamatan Playen tinggal di daerah yang kering dan tandus. Daerah ini setiap tahunnya mengalami tiga musim yaitu musim hujan, pancaroba, dan kemarau. Petani pada wilayah ini mengandalkan sistem tadah hujan dalam mengelola pertaniannya, artinya untuk menunjang sistem pertanian yang ditekuni keluarga hanya dapat mengandalkan curahan air hujan. Keluarga petani beradaptasi terhadap lingkungan yang tidak memiliki sumber air permukaan ini dengan cara intensifikasi atau ekstensifikasi lahan pertanian, rekayasa strategi nafkah atau strategi nafkah ganda, dan melakukan migrasi.

Adapun cara yang ditempuh keluarga petani antara lain sebanyak 19,0 persen menjadi buruh tani di lahan milik tetangganya, 2,0 persen berbisnis olahan hasil pertanian, 4,0 persen berjualan sembako dan sayuran, 4,0 persen berjualan di pasar, 2,0 persen menjadi makelar, 17,0 persen mengoperasikan mesin giling hasil pertanian/gergaji mesin, menjadi buruh serabutan $(3,0 \%)$, menjadi pengurus perkumpulan / organisasi / yayasan dengan bayaran rutin $(8,0 \%)$, menjadi wiraswasta lainlain $(5,0 \%), 9,0$ persen berusaha di tempat wisata air terjun Sri Gethuk dan Goa Ngrancang Kencono, 6,0 persen membuka usaha bengkel otomotif/elektronik, 1 persen menjadi pedagang kayu, dan 2 persen memiliki istri yang bekerja sebagai Pegawai Negeri Sipil.

Strategi nafkah tunggal keluarga petani di Kecamatan Playen dengan berbasis agraris adalah bertani, beternak, dan bertanam pohon jati. Strategi nafkah campuran keluarga petani di Kecamatan Playen adalah bertani sambil berwirausaha di luar pertanian serta melakukan migrasi. Hasil menunjukkan sebanyak 70,0 persen keluarga petani di Kecamatan Playen melakukan strategi nafkah campuran serta hanya 30,0 persen saja keluarga yang melakukan strategi nafkah bertani dan beternak. Pada desa dekat kota hanya 38,0 persen keluarga yang melakukan strategi nafkah bertani dan beternak, sedangkan sisanya melakukan strategi nafkah campuran $(62,0 \%)$. Sementara itu, pada keluarga di desa terpencil jumlah petani yang melakukan strategi nafkah bertani dan beternak hanya 22,0 persen.

\section{Kesejahteraan Keluarga Petani}

Tingkat kesejahteraan keluarga petani diukur dengan menggunakan indikator kesejahteraan BKKBN dengan memperhatikan terpenuhi atau tidak terpenuhinya indikator di setiap tingkatan tahapan keluarga sejahtera. Hasil penelitian pada Tabel 3 menunjukkan bahwa tidak terdapat satu pun keluarga dengan status prasejahtera di desa dekat kota sebanyak 38 persen keluarga termasuk ke dalam kategori keluarga sejahtera I, keluarga sejahtera II $(6,0 \%)$, keluarga sejahtera II $(11,0 \%)$, dan keluarga sejahtera III plus (17,0\%). Namun, terdapat empat keluarga dengan status keluarga prasejahtera di desa terpencil. Hal ini karena tidak terpenuhinya indikator rumah yang ditempati keluarga mempunyai atap, lantai, dan dinding yang baik. Secara total, diketahui bahwa keluarga miskin di kedua desa berjumlah 43,0 persen, sisanya sebanyak 57,0 persen dikategorikan sebagai keluarga sejahtera atau tidak miskin. Keluarga dengan status PraKS (prasejahtera) seluruhnya berada di desa terpencil.

Tabel 3 Sebaran keluarga berdasarkan tingkat kesejahteraan keluarga

\begin{tabular}{lrrrrrrr}
\hline $\begin{array}{l}\text { Tingkat } \\
\text { kesejah- } \\
\text { teraan } \\
\text { keluarga }\end{array}$ & \multicolumn{2}{c}{$\begin{array}{c}\text { Desa dekat } \\
\text { kota }\end{array}$} & \multicolumn{3}{c}{$\begin{array}{c}\text { Desa } \\
\text { terpencil }\end{array}$} & \multicolumn{2}{c}{ Total } \\
\cline { 2 - 8 } & $\mathrm{n}$ & $\mathrm{n}$ & $\%$ & $\mathrm{n}$ & $\%$ \\
\hline $\begin{array}{l}\text { Keluarga pra- } \\
\text { sejahtera }\end{array}$ & 0 & 0,0 & 4 & 8,0 & 4 & 4,0 \\
$\begin{array}{l}\text { Keluarga } \\
\text { sejahtera I }\end{array}$ & 18 & 38,0 & 20 & 40,0 & 39 & 39,0 \\
$\begin{array}{l}\text { Keluarga } \\
\text { sejahtera II }\end{array}$ & 3 & 6,0 & 3 & 6,0 & 5 & 5,0 \\
$\begin{array}{l}\text { Keluarga } \\
\text { sejahtera III }\end{array}$ & 11 & 22,0 & 12 & 24,0 & 23 & 23,0 \\
$\begin{array}{l}\text { Keluarga } \\
\text { sejahtera III }\end{array}$ & 17 & 34,0 & 11 & 22,0 & 28 & 28,0 \\
$\begin{array}{l}\text { Plus } \\
\text { Jumlah }\end{array}$ & 50 & 100,0 & 50 & 100,0 & 100 & 100,0 \\
\hline Keterangan: $\mathrm{n}=$ jumlah, \%=persentase & & &
\end{tabular}




\section{Pengaruh Karakteristik Keluarga, Kepemilik- an Modal Strategi Nafkah, dan Lokasi Tempat Tinggal terhadap Tingkat Kesejah- teraan Keluarga Petani}

Pada penelitian ini, model yang dibangun untuk menganalisis pengaruh karakteristik keluarga, kepemilikan modal strategi nafkah, dan lokasi tempat tinggal terhadap tingkat kesejahteraan keluarga petani memiliki koefesien determinasi (Nagelkerke $R$ Square) sebesar 0,440. Angka ini berarti bahwa model dapat menjelaskan sebesar 44,0 persen pengaruh karakteristik keluarga, kepemilikan modal strategi nafkah, dan lokasi tempat tinggal terhadap tingkat kesejahteraan keluarga petani. Sementara itu, sisanya $(56,0 \%)$ dijelaskan oleh variabel lain yang tidak diteliti dalam penelitian ini.

Hasil uji regresi logistik biner pengaruh variabel karakteristik keluarga, kepemilikan modal strategi nafkah, dan lokasi tempat tinggal terhadap tingkat kesejahteraan keluarga petani disajikan pada Tabel 4.

Tabel 4 Hasil uji regresi logistik biner variabel karakteristik keluarga dan modal strategi nafkah terhadap tingkat kesejahteraan keluarga petani

\begin{tabular}{|c|c|c|c|}
\hline \multirow[t]{2}{*}{ Variabel } & \multicolumn{2}{|c|}{$\begin{array}{c}\text { Tingkat } \\
\text { kesejahteraan } \\
\text { keluarga }\end{array}$} & \multirow[t]{2}{*}{ Sig. } \\
\hline & B & $\begin{array}{c}\operatorname{Exp} \\
(\beta)\end{array}$ & \\
\hline Konstanta & $-2,902$ & 0,055 & 0,410 \\
\hline $\begin{array}{l}\text { 1. Jumlah anggota } \\
\text { keluarga (Jiwa) }\end{array}$ & $-1,124$ & 0,884 & 0,597 \\
\hline 2. Usia suami (tahun) & $-0,054$ & 0,947 & $0,060^{*}$ \\
\hline $\begin{array}{l}\text { 3. Pendidikan suami } \\
\text { (tahun) }\end{array}$ & 0,027 & 1,028 & 0,780 \\
\hline $\begin{array}{l}\text { 4. Pengeluaran per } \\
\text { kapita } \\
\text { (Rp000/bulan) }\end{array}$ & 0,007 & 1,007 & $0,003^{\star \star}$ \\
\hline 5. Modal fisik (Rp000) & 0,000 & 1,000 & $0,027^{\star \star}$ \\
\hline $\begin{array}{l}\text { 6. Modal finansial } \\
\text { (Rp000) }\end{array}$ & 0,000 & 1,000 & 0,244 \\
\hline 7. Modal alam (skor) & 0,005 & 1,005 & 0,770 \\
\hline $\begin{array}{l}\text { 8. Modal sosial } \\
\text { (skor) }\end{array}$ & 0,028 & 1,029 & 0,390 \\
\hline $\begin{array}{l}\text { 9. Strategi nafkah } \\
\text { (Dummy } \\
0=\text { tunggal, } \\
1=\text { campuran) }\end{array}$ & $-0,016$ & 0,984 & 0,979 \\
\hline $\begin{array}{l}\text { 10. Lokasi ( } 0=\text { Desa } \\
\text { dekat kota, } \\
1=\text { Desa terpencil) }\end{array}$ & $-0,101$ & 0,904 & 0,898 \\
\hline Chi-Square & & $\begin{array}{c}39,674 \\
10\end{array}$ & \\
\hline Sig & & $0,000^{* *}$ & \\
\hline Nagelkerke $R^{2}$ & & 0,440 & \\
\hline
\end{tabular}

Hasil analisis yang disajikan menunjukkan bahwa tingkat kesejahteraan keluarga petani dipengaruhi secara positif signifikan oleh pengeluaran per kapita per bulan keluarga dan nilai modal fisik, sedangkan dipengaruhi negatif signifikan oleh usia suami. Hasil ini mengindikasikan bahwa setiap peningkatan besar pengeluaran keluarga akan meningkatkan kesejahteraan keluarga petani. Kedua, peningkatan nilai modal fisik akan meningkatkan kesejahteraan keluarga petani. Ketiga, setiap pertambahan usia suami pada keluarga petani dapat menurunkan tingkat kesejahteraan keluarga petani.

\section{PEMBAHASAN}

Keluarga petani tadah hujan melakukan upaya strategi nafkah lebih banyak. Hal ini dilakukan karena keluarga petani tadah hujan termasuk dalam kategori tidak sejahtera (43,0\%). Temuan ini memperkuat hasil penelitian Sumarti (2007), bahwa strategi nafkah ganda menjadi perilaku ekonomi yang menonjol yang dilakukan oleh petani perkebunan miskin, meskipun dalam penerapannya strategi adaptasi nafkah tetap disesuaikan dengan konteks sosio-budaya masyarakat lokal. Turasih dan Wibowo (2012) juga menyatakan hal yang sama, bahwa semakin luas lahan yang digarap oleh rumah tangga petani menyebabkan petani merasa aman dengan aktivitas nafkah pertanian saja. Sebaliknya, untuk petani miskin dengan lahan garapan sempit memiliki strategi nafkah yang semakin beragam (Turasih \& Wibowo, 2012). Tulak, Dharmawan, dan Juanda (2009) menyebutkan bahwa keluarga yang memiliki keunggulan dalam pencapaian tingkat ekonomi biasanya memiliki kelenturan dalam menyusun strategi bertahan hidup. Demikian pula Ellis (1998, 2000); Turasih dan Wibowo (2012); Widiyanto, Suwarto, dan Retno (2010); Cahyono, Nugroho, dan Indrajaya, (2007); Padhila dan Hoff (2011) juga menyatakan bahwa diversifikasi nafkah di pedesaan hanya dimungkinkan jika terdapat keberagaman sumber daya alam sebagai landasan livelihood platform. Strategi nafkah diarahkan pada komoditas yang tersedia, terlebih jika berlimpah di desa (Tefera, 2009). Dengan demikian dapat disimpulkan bahwa banyaknya strategi nafkah yang ditempuh oleh keluarga petani supaya pendapatan menjadi lebih banyak untuk mencukupi kebutuhan sehari-hari.

Pada penelitian ini, usia suami berpengaruh signifikan negatif terhadap tingkat kesejahteraan keluarga. Hal tersebut berarti setiap pertambahan usia suami menyebabkan 
penurunan tingkat kesejahteraan keluarga. Hal ini karena pertanian yang dilakukan secara tradisional sangat mengandalkan tenaga manusia yang masih kuat. Temuan ini memperkuat hasil penelitian yang dilakukan oleh Elmanora, Muflikhati, dan Alfiasari (2012) bahwa keluarga dengan usia ayah yang masih muda memiliki peluang sejahtera lebih besar dibandingkan dengan keluarga dengan usia ayah yang sudah memasuki usia pertengahan (dewasa madya). Kekuatan tubuh diperlukan untuk mengolah sawah dan ladang supaya menghasilkan produk pertanian yang lebih banyak yang pada gilirannya menentukan tingkat kesejahteraan objektif keluarga petani.

Penelitian yang telah dilakukan oleh Puspitasari, Puspitawati, dan Herawati (2013) menyebutkan bahwa keluarga yang sejahtera secara objektif termasuk dalam kategori tidak miskin. Kesejahteraan keluarga berhubungan signifikan dengan usia suami dan pengeluaran keluarga. Usia yang lebih muda diharapkan menumbuhkan produktivitas yang lebih baik. Penelitian yang dilakukan oleh Widyastuti (2012) membuktikan bahwa produktivitas pekerja berpengaruh terhadap tingkat kesejahteraan keluarga.

Tingkat kesejahteraan keluarga petani dipengaruhi oleh besarnya nilai pengeluaran per kapita keluarga. Pos-pos pengeluaran keluarga merupakan bahan untuk melihat tingkat kesejahteraan keluarga (Dewayanti, 2003). Pendapatan keluarga yang dibelanjakan untuk pengeluaran pangan dan nonpangan, kedua jenis pengeluaran ini dapat menjelaskan dengan baik bagaimana pola konsumsi masyarakat secara umum (Rambe, 2004). Keluarga yang memiliki pendapatan yang rendah akan menggunakan sebagian besar pendapatannya untuk pengeluaran pangan sebagai kebutuhan pokok. Namun, tingkat pendapatan yang baik akan memberi peluang lebih besar untuk membeli kebutuhan pangan dan nonpangan yang lebih baik dari segi kuantitas maupun kualitas. Temuan penelitian ini juga mendukung hasil penelitian yang sudah dilakukan oleh Johan, Muflikhati, dan Mukhti (2013) bahwa pendapatan keluarga per kapita per bulan berpengaruh signifikan terhadap kesejahteraan objektif. Keluarga dengan pendapatan yang tinggi memiliki peluang untuk lebih sejahtera dibandingkan dengan keluarga yang memiliki pendapatan yang rendah.

Hasil penelitian menunjukkan bahwa pemanfaatan modal fisik berpengaruh positif terhadap tingkat kesejahteraan keluarga petani di Kecamatan Playen. Aset akan berfungsi sebagai alat pemuas kebutuhan. Oleh karena itu, keluarga yang memiliki aset lebih banyak cenderung lebih sejahtera jika dibandingkan dengan keluarga yang memiliki aset terbatas. Hal ini juga sesuai dengan hasil penelitian Muflikhati et al. (2010) dan Iskandar (2007), bahwa aset berpengaruh signifikan terhadap kesejahteraan keluarga. Hasil penelitian juga mendukung temuan Moser dan Holland (1996) bahwa kemampuan masyarakat untuk mengatasi kesulitan ekonomi sebagian besar dipengaruhi oleh harta kekayaannya. De Haan (2000) menemukan kesimpulan yang kurang lebih selaras yaitu keluarga miskin akan berusaha mengamankan kecukupan kebutuhan pokok akibat tekanan sumber daya alam dan dalam kondisi kritis, keluarga akan mengubah strategi nafkah yang biasa dengan strategi nafkah yang baru menggunakan sumbersumber nafkah (modal alam, modal manusia, modal finansial, modal fisik, dan modal sosial).

Usia suami, pengeluaran per kapita, dan besarnya modal fisik merupakan 3 (tiga) hal yang memengaruhi tingkat kesejahteraan keluarga petani tadah hujan. Ketiganya merupakan rangkaian yang tidak terputus, yaitu bilamana usia suami masih muda dan tenaganya masih kuat maka suami mengerjakan lahan pertaniannya secara lebih baik sehingga menghasilkan produk pertanian yang lebih banyak. Produk pertanian yang tidak habis dikonsumsi sendiri digunakan untuk memperbesar modal fisik, dengan cara ini maka kesejahteraan keluarga petani tadah hujan dapat terwujud.

\section{SIMPULAN DAN SARAN}

Hasil analisis strategi nafkah keluarga petani di Kecamatan Playen Kabupaten Gunungkidul menunjukkan bahwa tujuh dari sepuluh keluarga petani melakukan strategi nafkah campuran, yang menunjukkan hampir sebagian besar keluarga petani melakukan strategi ini. Strategi nafkah tunggal yang banyak ditempuh oleh keluarga petani adalah bertani di sawah, ladang dan kebun milik pribadi serta hutan Perhutani, beternak dan menanam pohon jati sebagai investasi jangka panjang. Sementara itu, keluarga petani yang menjalankan strategi nafkah campuran antara lain bertani sambil berwiraswasta, istri sebagai PNS, dan salah satu anggota keluarga melakukan migrasi.

Tingkat kesejahteraan keluarga petani tadah hujan termasuk dalam kategori tidak sejahtera. Kesejahteraan keluarga petani tadah hujan dipengaruhi oleh usia suami, pendapatan per kapita keluarga, dan besarnya nilai aset fisik. 
Pertambahan usia suami cenderung menurunkan tingkat kesejahteraan keluarga petani tadah hujan. Kesejahteraan keluarga petani tadah hujan meningkat dengan bertambahnya pendapatan keluarga per kapita dan besarnya nilai aset fisik. Oleh karenanya, perlu adanya upaya penambahan pendapatan keluarga untuk meningkatkan kesejahteraan keluarga petani tadah hujan.

\section{DAFTAR PUSTAKA}

Alfiasari. (2008). Analisis modal sosial dalam pemberdayaan ekonomi keluarga miskin di Kelurahan Kedung Jaya, Kecamatan Tanah Sareal, Kota Bogor. Jur. IIm. Kel. \& Kons., 1(1), 29-42.

Cahyono, S. A., Nugroho, P., \& Indrajaya, Y. (2007, Januari). Alokasi Pengeluaran Rumah Tangga Penyadap Getah Pinus di Desa Somagede, Kabupaten Kebumen, Jawa Tengah. Jurnal Ilmu Kehutanan, 1(1).

Chambers, R., \& Conway, G. (1991). Sustainable rural livelihood: Practical Concepts for 21st Century, IDS Discussion Paper 296: IDS. Institute for Development Studies, Brighton.

De Haan. (2000). Globalization, localization, and sustainable livelihood. Sociologia Ruralis, 40(3), 339-365.

Dewayanti, R. (2003). Memahami persoalan perempuan pengusaha kecil. Jurnal Analisis Sosial, 8(1), 117-133.

[DFID] Departemen For International Development. (2000). Sustainable livelihood guidance sheet issues. [Internet]. Diambil dari http://www.sheltercentre.org/sites/ de fault/file. [diunduh pada 29 Januari 2014].

Elmanora, Muflikhati, I., \& Alfiasari. (2012). Kesejahteraan keluarga petani kayu manis. Jur. IIm. Kel. \& Kons., 5(1), 58-66.

Ellis, F. (1998). Household strategies and rural livelihood diversification. The Journal of Development Studies, 35(1).

(2000). The Determinants of rural livelihood diversification in developing countries. Journal of Agricultural Economic, 51, 289-302.

Gunarso, P. (2009). Pengelolaan sumber daya hutan di era desentralisasi. Gunarso P, Setyawati T., Sunderland T.C.H., \& Sackleton C., penerjemah. Bogor, ID: CIFOR.
Iskandar, A. (2007). Analisis praktik manajemen sumber daya keluarga dan dampaknya terhadap kesejahteraan keluarga di Kabupaten dan Kota Bogor (Disertasi). Program Studi Gizi Masyarakat dan Kesejahteraan Keluarga. Sekolah Pascasarjana, Institut Pertanian Bogor.

Johan, I. R., Muflikhati, I., \& Mukhti, D. S. (2013). Gaya hidup, manajemen keuangan, strategi koping, dan kesejahteraan keluarga nelayan. Jur. IIm. Kel. \& Kons., 6(1), 30-38.

Minamoto, Y. (2010). Sosial Capital and livelihood recovery: post-tsunami Srilanka as a case. Disaster Prevention and Management, 19(5).

Moser, C. O. N., \& Holland, J. (1996). Confronting Crisis: A Summary of household responses to poverty and vulnerability in four poor urban communities. Environmentally Sustainable Development Studies and Monographs Series No.7: The World Bank.

Muflikhati, I., Hartoyo, Sumarwan, U., Fahrudin, A., \& Puspitawati, H. (2010). Kondisi Sosial ekonomi dan tingkat kesejahteraan keluarga: kasus di wilayah pesisir Jawa Barat. Jur. Ilm. Kel. \& Kons., 3(1), 1-10.

Narayan, D., \& Cassidy, M. (1999). A dimensional approach to measuring social capital: development and validation of social capital inventory. Washington, DC: The World.

Olsson, L., \& Elmqvist, B. (2006). Livelihood diversification: Continuity and change in The Sahel. Geo Journal, 67, 167-180.

Ozturk, I. (2009). A Case on changing livelihood strategies of the community of Ban Non Saoe Village, Nakhon Ratchasima Province, Thailand. European Journal of Development Research, 21, 250-263.

Padhila, A. C. M., \& Hoff, D. N. (2011). Livelihood diversification strategy in rural properties: Water resources exploration in rural tourism activity. International Journal of Economic and Management Sciences, 1(3), 49-59.

Puspitasari, N., Puspitawati, H., \& Herawati, T. (2013). Peran Gender, Kontribusi Ekonomi Perempuan, dan Kesejahteraan Keluarga Petani Hortikultura. Jur. IIm. Kel. \& Kons., 6(1), 10-19. 
Puspitawati, H., Simanjuntak, M., \& Hayati, L. (2012). Kontribusi ekonomi dan peran ganda perempuan serta pengaruhnya terhadap kesejahteraan subjektif. Jur. IIm. Kel. \& Kons., 5(1), 11-18.

Rambe, A. (2004). Alokasi pengeluaran rumah tangga dan tingkat kesejahteraan: Kasus di Kecamatan Medan Kota Sumatra Utara (Tesis). Sekolah Pascasarjana, Institut Pertanian Bogor, Bogor.

Sajogyo. (1982). Modernization without development. The Journal of Social Studie, Bacca. Bangladesh.

[Sihati] Sistem informasi harga dan Produksi Komoditi. (2013). [internet]. Diambil dari http://hargajateng.org/sensus-pertanian2013.html. [diunduh pada 30 Juni 2015].

Scoones, I. (1998). Sustainable rural livelihood: A Framework for Analysis. IDS Working Paper No.72. Institute of Development Studies, University of Sussex. Brighton.

Siddique, T. (2003). Migration as a livelihood strategy of the poor: the Bangladesh case, Regional Conference on Migration, Development and Pro-Poor Policy Choices in Asia, 22-24 June, 2003, Dhaka, 1-23, www.livelihoods.org.

Sumarti, T. (2007). Kemiskinan petani dan strategi nafkah ganda rumah tangga pedesaan. Sodality: Jurnal Transdisiplin Sosiologi, Komunikasi, dan Ekologi Manusia, 1(2), 100-115.

Swastika, D. K. S., Hadi, P.U., \& Ilham, N. (2000). Proyeksi penawaran dan permintaan komoditas tanaman pangan. Bogor, ID: Pusat Penelitian Sosial Ekonomi Pertanian Bogor.

Turasih., \& Wibowo, S. A. (2012, September). Sistem nafkah rumah tangga petani kentang di Dataran Tinggi Dieng: Kasus Desa Karangtengah, Kecamatan Batur,
Kabupaten Banjarnegara, Provinsi Jawa tengah. Sodality: Jurnal Sosiologi Perdesaan, 196.

Tulak, P. P., Dharmawan, A. H., \& Juanda, B. (2009). Struktur nafkah rumah tangga petani transmigran: Studi sosio-ekonomi di tiga kampung di distrik Masni Kabupaten Manokwari. Sodality: Jurnal Transdisiplin Sosilogi, Komunikasi dan Ekologi Manusia, 203-220.

Tefera, T. L. (2009). Supply response, local reality and livelihood sustainability : The policy dillema of Khat (Catha Edulis) production in Eastern Ethiophia. International Journal of Agricultural Sustainability, 7(3), 176-188.

[ILO] International Labour Organization, [FAO] Food and Agriculture Organization. (2009). The Livelihood Assesment ToolKit/LAT.Publish by ILO and FAO. United Nations.

Widiyanto, Suwarto, \& Retno, S. (2010, Desember). Dinamika nafkah rumah tangga petani pedesaan dengan pendekatan Sustainable Livelihod Approach (SLA): Kasus Petani Tembakau di Lereng Gunung Merapi-Merbabu, Propinsi Jawa Tengah. Jurnal Agritext, 28.

Widodo, S. (2006). Migrasi internasional tenaga kerja pertanian di Kabupaten Bangkalan. Pamator, 3(2), 65-78.

(2011, Juli). Strategi nafkah berkelanjutan bagi rumah tangga miskin di daerah pesisir. Jurnal Makara, Sosial Humaniora, 15(1), 10-20.

Widyastuti A. (2012). Analisis hubungan antara produktivitas pekerja dan tingkat pendidikan pekerja terhadap kesejahteraan keluarga di Jawa Tengah tahun 2009. Economics Development Analysis Journal (EDAJ), 1(2). 